\title{
International military cooperation as an impetus for enriching terminological dictionaries: the English-Ukrainian context
}

\author{
Yuliya Denysiuk - Tetiana Serhiienko - Roman Serhiienko - Yuliia \\ Samoilova
}

DOI: 10.18355/XL.2021.14.02.19

\begin{abstract}
The article focuses on the problem of successful communication in the course of military translation. The significant part of this process is a translation of numerous military terms, acronyms, and abbreviations where a translator must consider the context of the military document to ensure the right translation, which is as close as possible to the original text meaning.

The research is based on the method of scientific observation during the classes and practical exercises in cooperation with NATO officers, the descriptive method, the method of comparison, which was used in the analysis of many textbooks and scientific articles. The use of the specific method of distributive analysis allowed the consideration of the context-dependent military terms and abbreviations.

This paper presents the results of the research, including, in particular, the outlining of the classification of military terms and abbreviations, accentuation on the skills and knowledge which are important for producing a correct translation of the military terms and abbreviations which, in its turn, may have correspondents in a target language or may not have ones. Last but not least, the article provides the most striking instances of translating military terms and abbreviations grouped by their types.

Reviewing the results, one can consider military translation as a context-based linguistic activity to a significant degree. The translator should have wide knowledge in the military sphere generally and in a concrete object of translation in part: artillery, ammo, IT-technologies etc. Besides English, itself is a language that develops exponentially, which invokes the growth of a variety of military terminology. As known, English is one of the two official languages of NATO. However, there are some differences in vocabulary and stylistic usage between the native languages of the Alliance member countries and English, so translators must take it into account in order to avoid misunderstandings.
\end{abstract}

Key words: military, terminology, abbreviations, methods, NATO, peacekeeping, translation, shortening, word combination, transcoding

\section{Introduction}

Successful communication in the military sector is ensured significantly by adequate translation of military terminology and specific acronyms and abbreviations. The military translation represents a separate demanding area of translation activity due to the possibility of dire consequences in case of wrong translation without context consideration. Adequate and quality translation requires correct, clear, and full transfer of peculiarities and content of the original text as well as its linguistic form while taking into account the structure, style, lexical and grammatical features. Military translation highlights the importance of precision since the translated material is often used as a basis for conducting military operations or serves as a basis for the MDMP - Military Decision Making Process.

Historically, the military field has always been connected with interlingual intermediacy. Military cooperation between Ukraine and NATO member-states began immediately after 1991 when the Independence of Ukraine was proclaimed.

XLinguae, Volume 14 Issue 2, April 2021, ISSN 1337-8384, eISSN 2453-711X 
The specificity of practical activity of military interpreter/translator was researched by I. Korunets, S. Vernikov, V. Archie, K. Torikai, and others (Korunets, 2003; Vernikov, 1977; Archie, 2007; Torikai, 2009.). Theoretical and practical aspects of military translation are included in many research papers, monographs, textbooks, and manuals of R. Meeniar-Beloruchev, V. Ostapenko, A.Shyriaev (military translation from/to the French language), N. Vietlov, H. Strelkovskyi, L. Azarkh, A. Panfilov, R. Yefimov, B. Boyko, L. Latyshev, A. Rodionov (military translation from/to the German language), L. Neliubin, A. Dormidontov, Yu. Spazhev, A. Philipov, H. Sudzilovskii (military translation from/to the English language).

The subject of the discussion is different translation methods of military terminology from English to Ukrainian. The research corpus of the article is based on professional notes accumulated within the time span of 4 years of working as an interpreter and teacher at the National Army Academy, Ukraine.

Gathering of theoretical and empirical material from main European and Eastern languages, systematization of foreign-language terminology bases of military field (simultaneously finding Ukrainian translation substitutes), creation of the theoretical basis of such practical activity as linguistic support of the Armed Forces of Ukraine is currently happening. Ukraine joined the NATO-led Euro-Atlantic Partnership Council in 1992 and then was involved in international peacekeeping activity. Since that time, Ukraine pledged to work onwards to meet the NATO standards. These standards are concerned first and foremost with the means of communication, terminology, staff procedures, and leading documents. Taking into account the intensification of the integration of Armed Forces of Ukraine into various programs of military cooperation, the need for highly qualified military translation has risen up. The need for specialists in the field requires the occurrence of special institutions. Therefore one can confidently foresee the birth of a national school of military translation in the notso-distant future.

Constantly developing military terminology, especially military abbreviations, has always drawn the attention of translation studies. It is due to the development of military technologies and changes in the countries' political courses of action. National specialists of military and scholarly fields, which in different ways are connected with the translation of military terms and with the peacekeeping activity, work together in order to correspond to the Alliance member states and to the partners of the Partnership for Peace program. To solve the problem of the standardization of military vocabulary means to overcome language barriers and master the NATO staff procedures. To quote I. Korunets, "interpretation and translation are an indispensable element of international, foreign policy and military activity" (Korunets, 2003: 33).

English language is the official language in the field of peacekeeping activity and acts as a means of communication for members of peacekeeping activity that are the representatives of different nationalities. The effectiveness of communication of all elements of multinational military forces during the execution of peacekeeping operations is based on the usage of "international professional English language" (Perepelytsia, 2002: 141). It should be noted that English in the widespread language in the world, and therefore, it develops fast and a little bit unpredictable. It draws an emerging of new military slang words that in an informal setting can be used as military terms. For example, it is actually impossible to find in the dictionaries the term "webbing" in the sense of "geodesic survey" of artillery pieces, but, according to authors' experience, some servicemen use it in that sense.

S. Yanchuk holds the belief that the premise for skillful mastering of a peacekeepers' working language by military contingent or the non-English speaking personnel or member-states of Partnership for Peace program is the development and introduction of a standard course, "English language for the military" which is being taught in the NATO member-states within the British Council project "Peacekeeping English" (translated by $Y u$. D.) (Yanchuk, 2013: 21). The need of effective communication of 
Peacekeeping activity subjects caused the creation of standardized common working language. S. Yanchuk suggests the term "peaceglish" in order to denote the international professional sublanguage of Peacekeeping activity. The term was coined with the help of two words, "peace" that is the main symbolic element of the term "peacekeeping" and the suffix "glish" used to denote the relation to the language (translated by Yu. D.) (Yanchuk, 2013: 22).

Today more than 120 countries have joined the Peacekeeping activity. Naturally, the need to use the unified working language of peacekeepers from different countries has become a central issue. In the process of its development, the working language is being enriched with many new lexical and phraseological units. However, the majorities of them lack fixed, and most importantly, correct translation correspondents. The notion of political-military discourse is of the utmost importance when it comes to the Partnership for Peace (PfP) programs - practical bilateral cooperation between NATO and individual partner countries, through which Ukraine, as well as other countries, can develop relationships with NATO, independently determining their own priorities of cooperation. The essence of PfP is the partnership between NATO and a partner country, which is formed on the individual basis, according to the individual needs of the country, and is implemented jointly at the level and with speed chosen by the government of each participating country. Ukraine joined PfP on February 8, 1994, after the signing of the relevant document. NATO experts provide practical advice on the implementation of jointly defined priorities and objectives within the above-mentioned NATO initiative. Within the PfP, the program our research has been concerned with is called Joint Multinational Training Group-Ukraine. It is the name for the training mission conducted by U.S. Forces in support of Ukraine. The U.S. will continue training and advising Ukrainian security forces until 2020, and JMTG-U will oversee defensive and security training for up to five battalions of the Ministry of Defense forces per year. The training is focused at partnering at the battalion level and below, building professional and capable Ukrainian units to defend Ukraine's sovereignty and territorial integrity. The headquarters is also working with our Ukrainian partners on the development of their training center at the International Peacekeeping and Security Center in Yavoriv, Ukraine. Other elements are working with the Ukrainian Army on a review and modernization of their doctrine. The corpus of this research will shed light on the doctrinal terms of the U.S. Army and its realia that pose a challenge for a translator/interpreter/teacher.

\section{Materials and Methods (Methodology)}

Since every research is built on a set of principles, the linguistic methodology of this article will combine the functional principle, which will help analyze language in action, together with explanatory principle, since bare description is not sufficient in modern linguistic paradigms. The aim of the article is to describe the translation abbreviations methods, using the scientific method of deduction, and to form a short dictionary of the most commonly used military abbreviations based on personal experience. The material under analysis is based on personal notes of the authors, every example that is discussed in this article has been taken from real life translating or interpreting practice or from the materials, used as a reference for the teaching of Ukrainian military cadets and officers at the National Army Academy with the aim of strengthening its NATO interoperability as well as its defense capabilities.

The research of military terms' translation has been conducted applying the following methods:

- the method of scientific observation: since September 1st, 2014 the authors of this article have been working as a full-time military interpreters/teachers at the National Army Academy, Ukraine.

XLinguae, Volume 14 Issue 2, April 2021, ISSN 1337-8384, eISSN 2453-711X 
- the descriptive method: the research involves objective analysis and description of the translation of military vocabulary. It is based on the idea of the use of Descriptive Translation.

- the method of comparison: is aimed at establishing identity, common and divergent features of the objects and phenomena under analysis. Comparative analysis helped us compare the results of our scientific observation, to conduct the overall analysis and synthesis of the theoretical material and examples, and to produce conclusions.

- the method of distributive analysis for the examining of the context-dependent military terms and abbreviations.

\section{Research}

\section{Background studies}

Modern linguistics considers language as a complex dynamic system. Being in constant motion, it is continuously developing thus has its past, present, and future. The problem of lexical variability and the study of new words are of special importance for modern linguists due to the exceptionally rapid economic and industrial development of society in the twentieth-twenty first centuries. Changes in terminology concern the meaning of the terms under the influence of linguistic and extra-linguistic factors, such as the progress of science, the development of wordbuilding capacity of terms, deeper understanding of the nature of concepts, enrichment of the vocabulary, etc. The system of concepts of each science is usually much wider than its terminological base. This discrepancy leads to continual growth in scientific terminology, since new concepts require proper consolidation of terminology. However, the development of individual branches of science requires constant specification and reviewing of the system of concepts and hence their verbal designation. This necessitates constant updating and improvement of specific terminology, which is impossible without conscious intervention of linguists and experts in the process of creating terms.

According to L. Turovska, if military terminology at the beginning of its development (the period of Kyivan Rus, Cossacks movement) was relatively closed, with a few number of system units, the modern scientific and technological military terminology is an open system, which is constantly updated with borrowings from related terminologies or relevant scientific disciplines (e.g. molecular physics and thermodynamics, quantum physics, macromolecular chemistry, etc.), technical industries (automation and computerization of military-technical equipment) due to new discoveries, the introduction of science. Via the development of science and technology the Ukrainian military terminology enriched with such terms in the aviation field as аеродинаміка, бомбардувальник-итурмовик, бортінженер, вертоліт-амфібія, винищувач надзвуковий, авіаційний ракетний комплекс, літак-торпедоносій; ground equipment (радар, пеленгатор, прилад керування артилерійним вогнем, радіозонд, радіотеплолокатор, протитанковий ракетний комплекс, шумопеленгатор); marine field (корабель-ракетоносій, човен підводний, торпеда, підводник, радіонавігачія, торпедоносій, тралер) and others (translated by $Y u$. D.) (Turovska, 2015: 4). Scientific works, in which borrowings are regarded as the main source of vocabulary enrichment, which helps improve their linguistic resources are written by M. Panov, H. Molochko, S. Ivanov, and others. According to another researcher V. Hak, borrowings are responsible for expanding the vocabulary only if there is insufficiency of word-building and semantic derivation, usually clog the language and stop the development of their own capabilities (translated by $Y u$. D.) (Turovska, 2015: 4). V. Hrechko stresses on the negativity of borrowings, which, to his mind, cause the loss of accessibility and understandability of terminological units, which causes obstruction in the way of development of the internal potential of the language (translated by Yu. D.) (Hrechko, 1976: 72). 
L. Symonenko suggests evaluating the borrowed term with the help of the following criteria: logical and linguistic suitability, shortness, word-building productivity (translated by Yu. D.) (Symonenko, 2001: 3-10).

Such modern languages as German, French, and especially English play an increasingly prominent role in borrowings in almost all fields of activity. Language relations between Ukrainian and English were not stable and were often indirect in nature: the main mediators were French, German, Russian, and Polish. The process of borrowing "anglicisms" had multilayer character, sometimes a parallel borrowing of the same lexical items through different languages in the west and east of Ukraine was observed, Turovska states. Today we observe the characteristic feature of the existence of direct, natural language contacts between the English and Ukrainian language. It is worth mentioning that bilingual terminological proficiency associated with profound study of foreign languages plays an important role in today's fastpaced society. This leads to the interaction of languages on the terminological level and promotes borrowing of foreign terms. Some of the internationalisms of English origin are: outsider - аутсайдер, authorization - авторизачія, escalation ескалація, engineering - інжиніринг, rating - рейтинг etc. (translated by $Y u$. D.) (Turovska, 2015: 4).

Nowadays, in the process of formation and standardization of Ukrainian military terminology, we must take into account all language material, which has been accumulated over the centuries, research and regulate it, choose the right and most suitable variants for the modern professional military vocabulary. L. Turovska argues that an important prerequisite for standardization of any modern terminology is the study of its history: the identification of certain linguistic phenomena caused by the development of terminology, their lexical-semantic and linguistic interpretation, and clarifying perspective means of term building and identifying models of term building that became obsolete. This provides the possibility to highlight the objective tendencies of terminology development. Without everything aforementioned, the modern standardization of the military vocabulary is impossible.

G. Strelkovskiy writes: "If we limit ourselves to military field only, we should admit that within this wide field there are many branches, which can be seen as various selfsufficient fields of knowledge or activity. Therefore, it is impossible to speak about the general concept of "military term". One should distinguish between the tactical, organizational, military-technical terms, terminology related to different sorts of troops and types of armed forces, etc. Different areas of military knowledge and activities have its own terminology. Within each of these areas, the meaning of the term becomes quite clear" (translated by Yu. D.) (Strelkovskiy, 1979: 83).

The specificity of the official style is reflected in the stylistic features peculiar exclusively to military documents. This style includes imperative mood, its nonpersonal nature, accuracy, which excludes double interpretation, logic, objectivity, clarity, officialism, stereotypedness, preciseness, generality, strictness, etc. Another characteristic is a special system of cliched expressions and terms that are different for each of the sub-styles. The process of standardization evolves mainly in two directions: a) the extensive use of existing, already used verbal forms, patterns (e.g. standard syntactic models that greatly simplifies and facilitates the process of writing the official documents, like: due to, in accordance with, etc.); b) frequent repetition of the same words, forms, constructions, with the aim of creating the uniformity of means of expressing thoughts in the same type of situations, refusing to use the expressive means of language (translated by Yu.D) (Znamenskaya, 2005: 113). There are a lot of special nomenclature terms, since they are associated with a huge number of objects and subjects of scientific and technical activity. General scientific and general technical terms, on the other hand, are usually rare, since there are a limited number of scientific and technical concepts. By their origin, they are already

XLinguae, Volume 14 Issue 2, April 2021, ISSN 1337-8384, eISSN 2453-711X 
polysemantic and indispensably linked with the common language. General words and general scientific terminology have the main communicative load in special texts (translated by $Y$ u. D.) (Gorelikova, 2002: 3). Such special texts are not uncommon for the military field.

\section{Types of military terminology}

According to Ch. Bally (1905: 65), in the lexical sphere, terms are the ideal means of language expression to which the scientific language inevitably strives. It is interesting to know that in the linguistic theory, the notion "term" is interpreted ambiguously. Some scientists consider a term to be an intentionally created language sign possessing a special terminological meaning; others believe that term is just a function of usual language sign correlating any word with a special sphere of its use, with a definite worldview of any of its fragment. A word becomes a term when it begins to denote scientific notions about objects, phenomena, features, comprising together with the other notions of the definite science sphere of the same semantic system (translated by Yu.D) (Boncharnikova, 2017: 130). Any lexical unit can function as a term if it correlates with a special notion of any scientific sphere and is a part of a definite denotative system.

V.M. Leichik interprets a term as a complex, multilayered formation in which a natural language substance and a logical substance constitute therefore under and upper layers, and its core is the terminological substance (translated by Yu.D) (Lisovskyi, 2010: 28). Thus, V.M. Leichik considers a term to be a constituting unit that is based on the general vocabulary, and that is a means and a result of the cognitive process. In accordance with V.M. Leichik's idea, it is approved that fixation is the secondary function of terms, and there is no doubt that "the study of the presently existing in the text terms will allow discovering of the essential peculiarities of their creation and application" (translated by Yu.D.) (Lisovskyi, 2010: 29).

One and the same term is always monosemous, meaning it cannot be compared with different semantic levels of use. However, this definiteness is traced only within one area of knowledge since, in another area, the same sign can denote a completely different concept or an absolutely different object of reality. However, within the framework of one area of human activity and knowledge, the term tends to remain monosemous. If the lexical meaning of the word is defined by the context, then the meaning of the term within one area of knowledge is not defined by the context. That is, the term is always associated with only one object within one area of knowledge in any context (translated by Yu.D.) (Strelkovskyi, 2015: 29).

A characteristic feature of any military document is the saturation of special terminology. The formation of military terms occurs in the usual ways that are characteristic of the English language word-formation: morphological, including affixation (e.g. maneuverability, missileer, rocketeer, analyst, rotary), word-building (warhead, countdown, target-seeking, hard-fought, nuclear-powered), conversion (to mortar, to officer), abbreviation (copter, chute, radar, FEBA, ROAD); lexicosemantic, denoting the transfer of meaning (Diesel - the inventor's name and the name of the type of internal combustion engine, Pentagon - the name of the building of the US Department of Defense, the US Department of Defense, the US military), the change in meaning ("acquisition" meant only acquisition, and now means the identification and interception of targets), broadening of the meaning ("to land" meant to go ashore, and now means to land on any surface, including water and stellar body; narrowing of the meaning ("cruiser" before denoted any sailing ship, now - just cruiser); by borrowing from other fields of science and technology (Strelkovskyi, 2015: 210).

Historical research of the Ukrainian military terminology indicates that the military vocabulary is one of the oldest professional terminologies. The formation of Ukrainian military terminology has been happening for centuries. This process clearly 
indicates periods primarily associated with specific social and political conditions of its formation.

The authors of this manuscript analyzed the peculiarities of translation of some military terms in national and historical context (Serhiienko, 2020a: 97-103).

Serhii Yanchuk, Candidate of Philological Sciences, professor of English at Taras Shevchenko National University in Kyiv, senior supervisor of Special Peacekeeping Centre of National Academy of Internal Affairs, suggests the definition of the military term in the context of peacekeeping activity and international military cooperation: "a way of interlingual and cross-cultural mediation, a type of special translation, which aims to provide quality and timely rendering of internal information by means of other language both in speech and writing, in the times of peace and war" (Yanchuk, 2010: 176).

Currently (based on the synchronic study), such groups of military terms are distinguished (translated by Yu.D.) (Turovska, 2015: 3).

1) Intralingual borrowings (when the term is coined to denote metaphorizaton of common lexical units, characteristic for many Ukrainian terminology systems). It proves the ability of the national language to accumulate, preserve and produce scholarly knowledge. This kind of borrowing was mostly characteristic of the military lexis of the XI-XII century due to the constant sectarian wars and the fighting with external enemies, which defined the way of life of common people that were forced to learn the military trade. This is why, in the process of the creation of military vocabulary, the majority of lexis belonged to everyday life. The saturation of a common language for the creation of the military terms can also be explained by the fact that this or that sphere of life cannot stand aloof the society's lifestyle. On the other hand, the maximum clarity of the term requires terminological monosemy, which can be reached with the help of reinterpreted common lexis:

a) proper names or reinterpretation of common words;

b) common Slavonic names and words;

c) the first foreign-language borrowings;

2) Old foreign-language borrowings (Polish language).

3) Borrowings from XVIII-XIX.

4) New foreign-language borrowings.

L. Neliubin mentions that the structure of modern military lexis is inconstant. Modern Ukrainian military lexis is in the state of flux due to the appearance of obsolete words (archaisms), constantly updating with the new terms during the reorganization of armed forces, the continuous appearance of new models of weapons and military equipment, and new methods of conducting armed conflict.

Usually, military lexis is subdivided into three main groups:

1. Military terminology, which denotes notions, directly connected with the military, armed forces, methods of conducting armed conflict, etc.

2. Military technical terminology that encompasses scientific and technical terms.

Emotionally colored military lexis (slang), represented by words and wordcollocations that are often used, usually in oral communication of the military representatives and that are stylistic synonyms of relevant military terms (translated by $Y$ u. D.) (Nelyubin, 1981: 13).

L. Neliubin further applied Yu. Spazhev's division of military terminology:

1. Terms, that denote military and political elements of foreign reality, identical to the elements of Ukrainian reality, e.g. callsign - позивний, field тапиаl - бойовий cmaтуm, human intelligence / HUMNT - агентурна розвідка, оverlay - схема на кальиі (оверлей), paramilitary forces - воєнізовані сили, range card - картка снайпера, safe lane - прохід у мінному полі. Usually, the group of such terms poses no difficulty in translation.

XLinguae, Volume 14 Issue 2, April 2021, ISSN 1337-8384, eISSN 2453-711X 
2. Terms that denote military and political elements of foreign reality, but are absent in the Ukrainian military-political reality, however, they have Ukrainian terminological correspondents, e.g. Battle Group - бойова група, Common Security and Defense Policy / CDSP - спільна політика Свропейського Союзу у сфері безпеки та оборони, cordon and search орегаtion - операчія з очеплення та обшуку, Multinational Brigade "East" - Багатонаціональна бригада "Схід” / MNB (East), Operations Security / OpSec - безпека операцій. The conditions for an adequate translation of these terms are translator's awareness of the structure of foreign countries' Armed Forces, as well as the understanding of the context, which may serve as a hint for a translator.

3. Non-equivalent terms - realia, as defined by Strelkovskiy (1979: 161). This group consists of terms that denote specific military-political and ethnocultural reality, e.g. honor killing - убивство за честь сім'ї, родини, клану, humanitarian intervention військове втручання з гуманітарних мотивів, proxy bomb - підривник-смертник. Translation of such terms requires particular attention of the translator to all the components.

\section{Translation of military terminology}

Despite the lengthy process of improving the state of the Ukrainian military terminology, the issue of the difficulty of translation and usage of special NATO terminology is still topical. The fruitful cooperation of NATO member states depends on many conditions and factors. Single working language and single standards of work are one of the main factors. Among Ukrainian researchers, military terminology from a translation viewpoint was studied by V. Balabin, V. Lisovskii, O. Chernishov (Balabin, 2008); Yu. Pashchuk, O. Lozova, S. Nazarova, P. Chernyk (Nazarova, 2005: 55).

Unfortunately, the NATO sublanguage and the difficulties of its translation lack the attention of national linguists and translation studies researchers. The lack of attention can be explained by the fact that samples, forms, and finished working military documents are confined to a narrow circle of engaged professionals. O. Yundina, in her article "Theory and practice of military translation in Ukraine" (2007) brings this problem up. She argues that often working documents remain in the organizations since written documents, notes, recordings of the conversations are not allowed public access. In this case, the practice of military translation will remain only to a limited circle of people, for military translators in the first place. The crucial component of military translation lies in providing the linguistic support of the Ukrainian Armed Forces during the events of international military cooperation since such events require professional translation support. Professional translation support of such events as peacekeeping and anti-terroristic operations as well as multinational military training depends on stable military terminology, military-specific language training, as well as research activity in these directions.

Authors of one of the first military translation manuals Yu. Spazhev and A. Philipov view military translation in two aspects: as practical linguistic activity and as an educational subject. Military translation as an area of practical linguistic activity is one of the types of special translation, with various military documents as its object. The relevancy of the military translation as a separate discipline is proved by the authors that present the list of peculiarities of oral and written military-themed linguistic activity, which belongs to the military field as a separate field of knowledge. In some cases, there are so many peculiarities that it is extremely hard for the unprepared person to understand them (both Russian and Anglophone in comparison with the Ukrainain language) (translated by Yu.D.) (Yudina, 2016: 15). Scholars mentioned the earlier distinction between the following peculiarities of oral and written military communication: 
1. Maximal saturation of military materials with military lexis. Military terms constitute the biggest part of written documents. Concerning oral communication of the foreign armies' soldiers, it is the military slang that constitutes the greatest part of military materials.

2. The presence of special idiomatic expressions in oral and written communication that are not used or are rarely used in a common literary language.

3 . The presence of some stylistic deviations from general literary norms, sometimes the deviations are substantial. In the English language, it is the briefness and dryness of the language (especially in the Army regulations or paperwork for combat missions), extensive usage of elliptical constructions, that along with the dryness and briefness of the English language, causes the usage of passive constructions and the substitution of subordinate clauses with absolute (nominative) constructions, participles and adverbial participles (gerunds).

Paperwork for combat missions is especially saturated with shortenings or abbreviations and acronyms that are used in the military field exclusively (Spazhev, 1963: 15-16). R. Miniar-Beloruchev has come to the conclusion that military translation can be defined as a scientific and technical translation of operational designation since it has a lot of texts saturated with military terminology. He proved it by the fact that in military translation, translators and interpreters deal with texts from communications field, business documentation, as well as other military documentation. What makes military translation different from sci-tech translation is that it presupposes specific forms of activity, e.g. Prisoner of War interrogation, detainee search, radio communication etc.

In the field of military translation, the first scholarly work belongs to V. Balabin, who researched the translation peculiarities of American military slang. V. Balabin started the series of translation studies that researched military sublanguage. He was also the first one to express the idea of creating the national school of military translation. The idea was the following: to provide quality training of professional translators in Ukraine, the one that would integrate the best accomplishments of modern philological and other humanitarian sciences, and introduce those accomplishments into the educational process (Balabin, 2002: 22). Later on, Balabin's idea was supported by $\mathrm{O}$. Yundina, who not only proved the necessity of creating the national school of military translation, but suggested well-grounded conditions for it to be created (translated by Yu.D.) (Yudina, 2016: 3). Balabin's student training manual "Fundamentals of military translation" published in 2004, is another great accomplishment that should be mentioned. He was working on the first edition of the manual alone. However, later on, V. Lisovskyi and O. Chernyshov in cooperation and under the editorship of $\mathrm{V}$. Balabin created a considerably extended variant of the manual in 2008. Another important work of V. Lisovskyi in the military translation discipline is the manual of military-technical translation in 2010 in three volumes (Lisovskyi, 2010). The co-authorship of V. Haponova, I. Yaremchuk, and I. Bloshchinskii has created the textbook "Military translation". O. Hukova has designed the textbook of practical course of military-specific language training for higher education establishment.

Despite the undeniable practical value of the above-mentioned textbooks, they still lack a full theoretical basis, which often causes simultaneous functioning of multiple terms denoting one notion. This is why the process of standardization of Ukrainian military terminology is an indispensable step on the long path of its modernization.

Generally, when translating military terms, the following methods are most commonly used: descriptive translation, loan translation (calque), transcoding (transcription and transliteration), lexico-semantic and lexico-grammatical substitutions.

S. Yanchuk further extends the methods of translation, and singles out:

XLinguae, Volume 14 Issue 2, April 2021, ISSN 1337-8384, eISSN 2453-711X 
1) description of the meaning of the Anglophone term, e.g. voluntary contributionin-kind - добровільний внесок не у грошовій формі;

2) loan translation (calque), e.g. small arms and light weapons (SALW) стрілецька зброя і легкі озброєння (СЗЛО);

3) partial or full transliteration, e.g. Eurocorps / European Corps - Сврокорпус / Європейський корпус, politicide - політіцид;

4) concretization of the word's meaning and by combined transcoding, e.g. jihadist - джихадист;

5) loan translation (calque) or by meaning extension, e.g. Spot Report (SPOTREP)

- термінова доповідь з місия подї; line of contact - лінія бойового зіткнення (Yanchuk, 2013: 56).

When translating military texts, one comes across words and word combinations of a complex nature. Such military texts contain varieties of shortenings, abbreviations, acronyms and pose many other peculiarities that cause different kinds of translational transformations to happen (Serhiienko, 2020b: 32-36).

\section{Translation of abbreviations as a special type of military terminology}

Shortenings, abbreviations, and acronyms play an important role in the scientific and technical functional style as a special type of nominative signs. They are characteristic of military documentation due to the language economy and language redundancy (translated by $Y u$. D.) (Yanchuk, 2013: 72). Well-known researcher of military and scientific-technical shortenings V. Borysov stated that the extensive use of the variety of shortenings is due to the scientific-technical revolution of the present time (translated by $Y$ u. D.) (Borisov, 1972: 3). Yu. Kocharian argued that the speeded up the process of abbreviation, and its application to the military field is happening mostly during wartime (translated by Yu. D.) (Kocharian, 2007: 29). Jespersen noted: "Abbreviations have parallels in other languages, but, apparently, they are nowhere as numerous as in modern English; they are, in fact, one of the most characteristic features of the development of the English language at the current stage" (Jespersen, 1949).

According to Spazhev and Phillipov's research, American and English combat documents (e.g. battle orders) consist of approximately $50 \%$ of shortenings of a different kind. A smaller number of shortenings appears in other types of written military documentation and in oral military-specific documentation (translated by Yu. D.) (Sparzhev, 1964: 16).

Abbreviations can be translated using lexico-semantic substitutions, descriptive translation, transcription/transliteration, and the translation of the full form, with the creation on its basis of a new abbreviation in the TL. The choice of translation method is determined by the type of the term. For abbreviations, the following methods are most commonly used:

1) Translation of the full form;

2) Lexico-semantic substitutions;

3) Transcription and transliteration;

4) Explication, or descriptive translation;

5) Translation of the full form and creation on its basis of a new Ukrainian abbreviation.

V. Karaban had conducted profound research concerning different types of shortenings in scientific-technical literature. He had concluded that different types of shortenings could constitute up to $50 \%$ of word use and $15 \%$ of word stock. This characteristic feature of scientific-technical texts is intrinsic to texts of military documentation, which allows using four main ways of their translation into Ukrainian, two of which are translation proper 1) with the help of the corresponding shortening in the TL; or 2) with the help of word or word-combination; 3) transcoding of the shortening itself; or 4) transcoding of the relevant word or word-combination 
(translated by Yu. D.) (Karaban, 2002: 488-451). Transcoding of the full form is rare and is used only for reproduction of names of companies, which are not independent subjects of peacekeeping activity. The following examples illustrate the most commonly used translation of abbreviation in the military sector.

1. Translation with the corresponding shortening: DMZ (Demilitarized Zone) - ДМЗ (Демілітаризована зона); DPKO (Department of Peacekeeping Operations) ДОПМ (Департамент операцій з підтримки миру); ISAF (International Security Assistance Force) - МСББ (Міжнародні сили сприяння безпеці в Ісламській Республіці Афганістан);

2. Translation with the corresponding full form or word or word-combination: AOR (Area of Responsibility) - зона відповідальності; CIMIC (Civil Military Cooperation) - цивільно-військове співробітництво; EOD teams (Explosive Ordnance Disposal teams) - групи знешкодження вибухонебезпечних предметів; IED (Improvised Explosive Device - саморобний вибуховий пристрій; PMC (Private Military Company) - приватна компанія воєнізованої охорони; PSC (Private Security Contractor) - приватна компанія-підрядник, щзо надає послуги у сфері безпеки; ROE (Rules of Engagement) - Правила застосування сили; VBIED (Vehicle-borne improvised explosive device) - транспортний засіб із саморобним вибуховим пристроєм.

3. Transcoding (transcribing or transliteration) - OPORD (Operational order) ОПОРД (бойовий наказ/оперативний наказ); FRAGO (Fragmentary order) ФРАГО (частковий наказ, частковий бойовий наказ), IFOR (Implementation Force) - IФОР (Сили Виконання Угоди у Боснії і Гериеговині); KFOR (Kosovo Force) - КФОР (Міжнародні сили з підтримки миру в Косово); MEDEVAC (Medical Evacuation) - МЕДЕВАК (медична евакуація).

Certain complexity in the translation of shortenings lies not only in the absence of corresponding Ukrainian forms in the dictionaries but also due to the widespread notion of homonymy (Table 1).

Table 1. Homonymy in the translation of shortenings

\begin{tabular}{|l|l|l|}
\hline \multicolumn{1}{|c|}{ Abbreviation } & \multicolumn{1}{c|}{ Full form } & \multicolumn{1}{c|}{ Translation (Ukrainian) } \\
\hline $\mathrm{AA}^{1}$ & Air armament & Авіаційне озброєння \\
\hline $\mathrm{AA}^{2}$ & Air army & Повітряна армія \\
\hline $\mathrm{AA}^{3}$ & Air-to-air & Класу «повітря-повітря» \\
\hline $\mathrm{AA}^{4}$ & Alerting authority & $\begin{array}{l}\text { Повноваження на приведення } \\
\text { військової частини у бойову } \\
\text { готовність }\end{array}$ \\
\hline $\mathrm{AA}^{5}$ & Район бойових дій \\
\hline $\mathrm{AA}^{6}$ & Area of action & Шлях підходу \\
\hline
\end{tabular}

In this case, the role of the context is crucial. For example, translation of the acronym "CONPLAN" will depend on the context since this shortening has three similar meanings, even though they are not identical: 1. Contingency Plan - план дій $в$ бойовій обстановиі; 2. Concept Plan - план-задум; 3. Concept of Operation Plan план-задум операциї / бою.

A common mistake while translating shortenings is the inability to identify the functional load of acronyms, which, as was previously mentioned, are characteristic of military texts. It leads to the wrong interpretation of their meaning.

According to V. Borisov, an acronym is a shortened word, created with the help of initial letters or initial elements of words of word-combination, which is similar or identical in its form (or phonetic structure) with common words (translated by $Y u$. D.)

XLinguae, Volume 14 Issue 2, April 2021, ISSN 1337-8384, eISSN 2453-711X 
(Borisov, 1972: 170-171). Considering their functions, S. Yanchuck (2013: 75-76) distinguishes the following groups of acronyms (Table 2).

\section{Table 2. Military acronyms}

\begin{tabular}{|c|c|}
\hline $\begin{array}{l}\text { NATO Standard } \\
\text { Phonetic Alphabet }\end{array}$ & $\begin{array}{l}\text { - represents special system of letters denomination in the } \\
\text { English language. For example, ECHO-nominal sound } \\
\text { denomination of the English letter " } e \text { ". }\end{array}$ \\
\hline $\begin{array}{l}\text { Proword } \text { (procedure } \\
\text { word) or procedure } \\
\text { expression }\end{array}$ & $\begin{array}{l}\text { - is used in radiotelephone communication and radio } \\
\text { traffic activity. For example, WILCO (I understand and } \\
\text { will comply. - Зрозумів. Виконую.) }\end{array}$ \\
\hline Brevity code & $\begin{array}{l}\text { For example, ECHO (Positive SEESAW / EWWS } \\
\text { electronic warfare weapons system / System M / Mode X } \\
\text { reply.) - ЕКО (Позитивні аномалії Північно- } \\
\text { Атлантичного температурного коливання / засоби } \\
\text { радіоелектронної боротьби (РЕБ) / Система М / } \\
\text { Відповідь у режимі Х.) }\end{array}$ \\
\hline Callsign & $\begin{array}{l}\text { For example, ECHO (Call sign for electronic warfare test } \\
\text { range at China Lake) - EКО (Позивний полігону для } \\
\text { випробовування засобів РЕБ в Чайна Лейк) }\end{array}$ \\
\hline $\begin{array}{l}\text { Standartized military } \\
\text { term }\end{array}$ & $\begin{array}{l}\text { - is used in NATO documents and publications. For } \\
\text { example, ECHO (evolutionary capability for HQ } \\
\text { operations) - (еволюиійний потенціал для штабних } \\
\text { операиій). }\end{array}$ \\
\hline $\begin{array}{l}\text { Names } \\
\text { organizations }\end{array}$ & $\begin{array}{l}\text { For example, ECHO (European } \text { Community } \\
\text { Humanitarian Office) - «ЕКО» Бюро європейського } \\
\text { співтовариства з гуманітарних питань / European } \\
\text { Cотmіssion's Humanitarian Aid Office }- \text { Бюро } \\
\text { Європейської Комісії 3 питань гуманітарної } \\
\text { допомоги. }\end{array}$ \\
\hline
\end{tabular}

The practice of using abbreviations most of the time is a characteristic feature of military discourse. The wide usage of abbreviations means brief, laconic, and clear expression with the aim of eliminating ambiguous interpretation.

\section{Methods of translating abbreviations as a particular type of military terminology}

While translating and conducting classes with the military officers and cadets of the National Army Academy, the following methods are most commonly utilized:

1) translation with the corresponding shortening;

2) translation with the help of word or word combination;

3) transcoding - transcription or transliteration.

Military abbreviations are used very often, and it implies some difficulties for nonnative speakers to understand the language. Based on their own experience, authors have formed 3 short dictionaries of the most commonly used abbreviations for the Ukrainian servicemen.

\subsection{Translation with the corresponding shortening}

Such a kind of translation is commonly used when corresponding shortenings are in widespread use in the native forces unit. Below are some examples of translation with the corresponding shortenings.

AGL (automatic grenade launcher) - АГC (автоматичний гранатомет станковий); 
AI (area of influence) - 3В (зона впливу);

AoI (area of interest) - 3I (зона інтересу)

Area of operations (AO) - 3В (зона відповідальності) / О3 (оперативна зона);

BCT (brigade combat team) - БТГр (бригадна тактична група).

More examples of such kind of translation could be found in Appendix A.1.

\subsection{Translation with the corresponding complete form of word or word- combination}

If there is no correct correspondence for the shortening of translator hesitates whether it matches exactly, then full of explanatory translation must be provided.

1st SGT (first sergeant) - головний сержант роти;

ACE report (ammunition, casualty, equipment) - доповідi про о/с та боєприпаси (доповідь про втрати серед о/с та наявність боєприпасів, доповідь про втрати та боєприпаси);

3D's (direction, distance, description) should be called out and passed back in information - встановити та передати по команді інформацію про ворога (напрямок, відстань та сили ворога);

MRAP (Mine Resistant Ambush Protected) - машини із захистом від мін.

More examples are listed in Appendix A.2. Besides, some examples of the UkrainianEnglish translation are listed below.

Ukrainian acronyms examples that are translated in English by words or word combinations:

БТ (бронебійно трасуючий снаряд) - armor piercing tracer;

$3 О O$ (захист, оборона, охорона) - protection;

ОТ (осколково-трасуючий снаряд) - fragmentation projectile;

ОФ3 (осколково-фугасний запалювальний снаряд) - high explosive;

ПТКР (ПТУР - calque from rus.), протитанкова керована ракета - antitank guided missile.

Let's consider the issue connected to the angle measurement system. In the military, the milliradian unit is used for angle measurement due to the simplicity and linearity of conversions. In the military 1 milliradian usually is abbreviated to "mil". But actually, military angle measuring unit mil is not exactly equals to milliradian but the number that can be handled easily. In different native armed forces, full circle consists of 6,400 mils for NATO countries, 6,000 "mils" - in former Warsaw Pact countries per turn instead of $360^{\circ}$ or $2 \pi$ radians ( $\approx 6283$ milliradians). Hence, it is very important in the multinational environment to understand that there are at least two angle measurement units called "mil" and they must be distinguished. Otherwise, a mistake up to 24 degrees could be made in the azimuth measuring, which is unacceptable for gunnery and land navigation. One should note that in written speech, the delimiter ""(hyphen) is used for so-called here "Warsaw Pact mil" system. It delimits hundreds of mils. In the spoken speech, the servicemen should arrange in advance which system is used: NATO mils or "Warsaw Pact mils". It should be noted that term "mil" is also used to designate a $1 / 1000$ of inch in some applications.

\subsection{Transcoding}

Transcription and transliteration are quite common while translating abbreviations; however, usually, the transcoded versions are accompanied by explication or decryption of a kind.

CASEVAC (Casualty evacuation) - КЕЗЕВАК (медична евакуачія поранених);

FRAGO (Fragmentary order) - ФРАГО (частковий наказ, частковий бойовий наказ)

More examples are provided in Appendix A.3. Besides, some examples of the Ukrainian-English translation are listed below.

XLinguae, Volume 14 Issue 2, April 2021, ISSN 1337-8384, eISSN 2453-711X 
БМП (бойова машина піхоти) - BMP (IFV - Infantry Fighting Vehicle);

БМД (бойова машина десанту) - BMD (AIFV - Airborne Infantry Fighting Vehicle);

БTP (бронетранспортер) - BTR (APC - Armored Personal Carrier).

The tendency in the English language is to use original abbreviations as they are. That is, instead of translating the BMP into an "Infantry Fighting Vehicle" or BTR into an "Armored Personal Carrier", it is more convenient, especially in the context of international training, to use names of concepts that everybody is familiar with. The origin of the names depends on the manufacturer of the weapon systems or tactical vehicles. However, sometimes one member-state likes to find the correspondent or similar notion in their culture, that is, draw parallels and use identical or similar notions interchangeably. For example, the American word "coax" refers to a co-axial machine gun, which is a machine gun fitted to a co-axial mount as a secondary weapon besides a vehicle's main weapon. In Ukrainian the descriptive translation is "спарений із гарматою кулемет". While on BMPs the standard gun is called PKT (Kalashnikov's machine gun tank version) - ПКТ (кулемет Калашникова танковий $K K T$ ), American standard co-axial gun is M240C is mounted on M1A2 Abrams, T$90 \mathrm{M}$ etc. Naturally, the American military tends to refer to our version of a co-axial gun as coax. Oftentimes, especially in the field environment, instead of abbreviations, you will hear the caliber of the weapon system. For example, the canon of the BMP will be referred to as 30 Mike Mike, the AK assault rifle as 7.62 Mike Mike.

\section{Findings}

Based on the authors' personal experience of working in the military translating field, 142 examples of commonly used military abbreviations terminology were analyzed. The research has highlighted three main methods of translating abbreviations as a special type of military terminology: 1) translation with the corresponding shortening;

2) translation with the corresponding full form of word or word-combination;

3) transcoding.

It has been discovered that the most applied translation method turned out to be the method of translation with the corresponding full form of word or word-combination with the corresponding. The example of "mil" angle measurement unit translation accentuates the necessity of this method exploitation in doubtful cases.

\section{Discussion}

As we see, the abbreviations are often used by the military in formal as well as informal settings. The translation of abbreviations depends on whether the correspondent in the target language exists and whether it is possible to create a successful translation variant that will be used by the military. If neither option is possible, explication of the abbreviation is the quickest and safest way out.

\section{Conclusion}

The military translation is based on the broad use of military abbreviations, which are often used by servicemen in a formal setting as well as in an informal one. The translation of abbreviations depends on whether the correspondent in the target language exists and whether it is possible to create a successful translation variant that will be used by the military.

It should be acknowledged that military texts are different from other kinds of texts. In view of the above, military translation poses many challenges and difficulties for the translator. First of all, the military translator must possess adequate competence in selecting the precise term. Additionally, s/he should be familiar with the military equipment and how they operate. S/He must have mastery of military jargon and slang language used in the military field. Also, s/he should have the necessary 
knowledge in advanced sciences such as IT, economics, and politics so s/he can have the adequate information to acquire the needed skill when working on military texts.

Nowadays, Ukraine participates intensively in international peacekeeping operations, for which the working language is English, where abbreviations are used extensively. In its turn, it makes the translation more complex, and it is imperative to make correct translation otherwise, it could cause negative consequences.

\section{Bibliographic references}

KORUNETS, I.V. 2003. The theory and practice of translation (aspect translating): guide. Vinnytsia. pp.33, 36-51.

VERNIKOV, S M. 1977. Military translator's notes. Sverdlovsk: Sredne-Uralskiy book publisher.

ARCHIE, V. 2007. Guidance for the Development and Publication of NATO Terminology. North Atlantic Council.

TORIKAI, K. 2009.Voices of the invisible presence: diplomatic interpreters in postWorld War II Japan. Amsterdam and Philadelphia: John Benjamin's publishing Company.

PEREPELYTSIA, H. 2002. The Ukrainian peacekeeping activity: the cooperation between NATO and other European defense agencies. Kyiv: Stylos. pp.141.

YANCHUK, S.YA. 2013. The peculiarities of translation of English-language military documentation of UN and NATO peacekeeping missions. Kyiv: Lohos. pp. 21-22.

TUROVSKA, L. 2007. The peculiarities of modern Ukrainian military terminology genesis. Available online: http://lib.chdu.edu.ua/pdf/naukpraci/philology/2007/67-5418.pdf

HRECHKO, V. 1976. What should be the term? Actual problems of lexicology and word formation, Vol. 5. pp. 48-109.

SYMONENKO, L. 2001. Ukrainian scientific terminology: state and prospects of development. Ukrainian terminology and modernity. Kyiv. pp. 3-8, 10.

STRELKOVSKIY, G.M. 1979. The theory and practice of military translation: German. Moscow: Voenizdat. pp. 83, 210.

ZNAMENSKAYA, T. 2005. The English language stylistics. Basics Course. Moscow. pp. 113.

GORELIKOVA, S. 2002. The nature of the term and some features of terminology in English. Bulletin OGU 6. pp. 3. Available online: http://cinref.ru/razdel/ 02200inostran_izik/03/ 162551.htm.

BALLY, Ch. 1905. Precis de stylistique. Esquisse d'une methode fondee sur l'etude du francais moderne. Geneva: A. Eggiman.

BONCHARNIKOVA, E. 2017. To the problem of the term "interdisciplinarity" Astrakhan State Technical University. Astrakhan. pp. 130. Available online: https://books.google.com.ua/books?id=5S_zAgAAQBAJ\&pg=PA130\&lpg=PA130\& $\mathrm{dq}=$ leichik+terms\&source $=\mathrm{bl} \&$ ots $=0 \mathrm{GANbRS} 2 \mathrm{mD} \&$ sig $=6 \mathrm{JVc} 8 \mathrm{f} 2 \mathrm{RMdKQUhIVts} 2 \mathrm{il}$ GPUZc\&hl=ru\&sa=X\&ved=0ahUKEwjru8PohJzUAhXJWSwKHVAtAuwQ6AEIJjA $\mathrm{A \#} \mathrm{v}=$ onepage $\& \mathrm{q}=$ leichik $\% 20$ terms $\& \mathrm{f}=$ false.

LISOVSKYI, V. 2010. Technical and military translation: a guide. Kyiv: Military Institute of Taras Shevchenko National University of Kyiv. pp. 28-29.

STRELKOVSKYI, G.M. 2015. Scientific and technical translation. Moscow: Prosveshchenie. 29 p.

SERHIIENKO, T.M. - DENYSIUK, Yu. I. - SERHIIENKO, R.V. 2020a. The peculiarities of the translation of some English military terms relating to armament and tactics of the Armed Forces of Ukraine. Scientific bulletin of Kherson state university. Series 1. Kherson: Helvetika. pp. 97-103. DOI: https://doi.org/ 10.32999/ksu2663-3426/2020-1-15.

XLinguae, Volume 14 Issue 2, April 2021, ISSN 1337-8384, eISSN 2453-711X 
YANCHUK, S.YA. 2010. Peculiarities of translation support of international military cooperation events. Material of the International scientific and practical conference " Military education present and future ". Kyiv: Military Institute of Taras Shevchenko National University of Kyiv. pp. 176.

NELYUBIN, L.L. - DORMIDONTOV, A.A. - VASILCHENKO, A.A. 1981. The military translation: textbook. Basics Course. Moscow: Voenizdat. 113 p.

BALABIN V.V. 2004. The basics course of military translation: English. Kyiv: Lohos.

BALABIN, V.V.- KISOVSKYI, V.M. - CHERNYSHOV, O.O. 2008. The basics course of military translation: English. Kyiv: Lohos.

NAZAROVA, S.V., - PASHCHUK, YU.M. 2005. English-Ukrainian and UkrainianEnglish dictionary of peacekeeping and military terminology. Lviv. Lviv Military University.

PASHCHUK, YU.M. - CHERNYK, P.P. 2007. Business English for the military men: a study guide. Lviv: Lviv Army University.

PASHCHUK, YU.M. - LOZOVA, O.T. 2005. Dictionary of abbreviations and acronyms: peacekeeping vocabulary. Lviv: Lviv Army University.

YUDINA, O. The theory and practice of the translation in Ukraine. Available online: http://papers.univ.kiev.ua/1/inozemna_filologija/articles/yundina-o-theory-and-

practice-of-military-translation-in-ukraine_14874.pdf

SPAZHEV, YU.A. - FILLIPOV, A.A. 1963. The course of military translation: English. Moscow: Voenizdat.

BALABIN, V. 2002. Professional skills of the military translator. Linguistic and conceptual pictures of the world, Vol. 7, $22 \mathrm{p}$.

LISOVSKYI, V. - BALABIN, V.V. 2010. Military and technical translation: English. Textbook. Vol 1. Kyiv: Military Institute of Taras Shevchenko National University of Kyiv.

LISOVSKYI, V. - BALABIN, V.V. 2010. Military and technical translation: English. Textbook. Vol 2. Kyiv: Military Institute of Taras Shevchenko National University of Kyiv.

LISOVSKYI, V. - BALABIN, V.V. 2010. Military and technical translation: English. Textbook. Vol 3. Kyiv: Military Institute of Taras Shevchenko National University of Kyiv.

YANCHUK S.YA. 2013. The peculiarities of translation the military documentations of military missions UN and NATO. Kyiv: Lohos. pp. 56, 75-76.

SERHIIENKO, R. V. - DENYSIUK, Yu. I. 2020b. To the issue of translation some English military terms in nationality context. Material of the International scientific conference "Priority development fields of the European research area". Riga, Latvia: Baltia Publising. pp. 32-36. DOI: https://doi.org/10.30525/978-9934-588-84-6-9.

KOCHARIAN, Yu. G. 2007. Abbreviation as linguistic phenomena [Text]: (by the examples of English military vocabulary). In: Vestnik Moskovskogo universiteta. Moskow: Lingvstika i mezhkulturnaja kommunikacia. vol. 19, n. 3. pp. 26-38.

BORISOV, V.V. 1972. Abbreviation and Acronym. Military and Scientific and technical reductions in Foreign Languages. Moscow. 3, pp. 170-171.

JESPERSEN, O. A. Modern English Grammar on Historical Principles. Available online: http://arrow.latrobe.edu.au:8080/vital/access/manager/Repository/latrobe:34325

SPARZHEV, Yu. A. - FILLIPOV, A.A. - YURIEV, E.A. 1964. The Course of English translation. Vol. 1. Moscow: Voenizdat. 16 p.

KARABAN, V.I. 2002. The translation of technical and scientific literature. Grammatical difficulties, lexical, terminological, and genre-stylistic problems. Vinnytsia: Nova Knyha. pp. 488-451. 
Words: 9858

Characters: 70557 (39,20 standard pages)

assoc. prof. Yulia Denysiuk

Hetman Petro Sahaidachnyi National Army Academy

32 Heroiv Maidany Street, Lviv

Ukraine

yuliyadenysiuk@gmail.com

assoc. prof. Tetiana Serhiienko

Hetman Petro Sahaidachnyi National Army Academy

32 Heroiv Maidany Street, Lviv

Ukraine

tanyasergh@gmail.com

assoc. prof. Roman Serhiienko

Hetman Petro Sahaidachnyi National Army Academy

32 Heroiv Maidany Street, Lviv

Ukraine

romanserg69@gmail.com

Scopus Author ID: 57201779202

assoc. Prof. Yulia Samoilova

Sumy branch of Kharkiv National University of Internal Affairs

24 Myru Street, Sumy

Ukraine

samoilova_yulya@ukr.net 


\begin{abstract}
Appendixes
A.1. Examples of translation with the corresponding shortening

$\mathrm{CP}$ (tactical command post) - КСП (командно-спостережний пункт/ передовий спостережний пункт/ бойовий/ тактичний командний пункт);

Deliberate CP (checkpoint) - постійний КПП (контрольно-пропускний пункт);

DMZ (Demilitarized Zone) - ДМЗ (Демілітаризована зона);

DPKO (Department of Peacekeeping Operations) - ДОПМ (Департамент операиій з підтримки миру);

EXPRO (exercise procedures) - ППЗ (прочедури проведення заняття);

Flare - РОП (ручний освітлювальний патрон), сигнальні ракети;

ISAF (International Security Assistance Force) - МСББ (Міжнародні сили сприяння безпеиі в Ісламській Республіці Афганістан);

JMTG-U (Joint multinational training group Ukraine) - ОБТГ-У (об'єднана багатонаціональна тренувальна група Україна);

Hasty CP (checkpoint) - тимчасовий КПП (контрольно-пропускний пункт);

Key sustainment tasks - ключові завдання МТЗ;

LDA's (Linear Danger Areas) - ПНЗ (прямолінійні небезпечні зони);

LOA (line of advance) - напрям наступу;

LOA( Limit of Advance) - ГРП (Граничний рубіж просування);
\end{abstract}

LP/OP (listening post/observation post) - ПП/СП (пункти прослуховування /спостережні пункти);

MANPADS / MPADS (man portable air defense system) - ПЗРК (переносний зенітно-ракетний комплекс);

MOPP (mission oriented protection posture) - 313 від ЗМУ (засоби індивідуального захисту від зброї масового ураження);

Main CP (command post) - основний КП (командний пункт);

NAI (named area of interest) - РОУ (район особливої уваги);

$\mathrm{NBC}$ (nuclear, biological, chemical weapon) - ЗМУ (зброя масового ураження);

NVD / NODs (night vision device/ night optical/observation device) - ПНБ (прилад нічного бачення);

OP (Observation Post) - СП (спостережний пост);

Concealed Observation post - секрет,

Open OP - СП (спостережний пост);

PACE plan (primary, alternate, contingency, emergency) - план ПАНА, план ГАЗА (4 альтернативні методи інформації: первинний або головний, альтернативний, надзвичайний, аварійний);

SALW (small arms and light weapons) - СЗЛО (стрілецька зброя і легке озброєння);

SLF (section live fire) / PLF (platoon live fire) - БСВ (бойові стрільби відділень/взводів);

TOC (tactical operation center) - ТОЦ - тактичний оперативний центр (battalion level);

TCP (traffic control point/ checkpoint) - КПП (контрольно-пропускний пункт);

TSP (training support package) - НМБ (навчально-матеріальна база).

\title{
A.2. Examples of translation with the corresponding full form of word or word- combination
}

AAR (After Action review) - підведення підсумків, розбір результатів виконання завдання;

AO for the mission (area of operations) - район, в якому проводитиметься операиія;

AOM (after operations maintenance) - технічне обслуговування після проведення операиій;

AOR (Area of Responsibility) - зона відповідальності; 
AXP (ambulance exchange point) - пункт обміну пораненими, пункт переправи поранених;

BLUFOR - ротаційний підрозділ;

CEO (Chief executive officer) - командир роти, головнокомандувач (також, президент США);

CIMIC (Civil Military Cooperation) - цивільно-військове співробітництво;

CLS (combat life saver) - бойовий санітар;

$\mathrm{CO}$ (Commanding officer) - командир роти;

COA (course of action) sketch- схема варіанту дій;

COMMs (communications) - засоби зв'язку;

CPX (command post exercise) - командно штабні навчання;

CCP (casualty collection point) - пункт збору поранених;

CoIST (company intelligence support team) - ротна розвідувальна група підтримки;

Crossing LD (line of departure) now - висуваємося 3 вихідного рубежа для виконання бойового завдання;

DP (Dismount point) - рубіж спішування, пункт спішування;

EEFI (essential elements of friendly information) - основі розвідувальні відомості про свої сили та засоби;

EOD (Explosive Ordnance Demolition) - інженерні підрозділи, сапери;

EOD teams (Explosive Ordnance Disposal teams) - групи знешкодження вибухонебезпечних предметів;

EPW and Search - група зачистки та по роботі з військовополоненими;

EPW teams (Enemy Prisoner of War team) - спеціальні групи (група для роботи з військовополоненими);

Enemy KIA (killed in action) - знищені солдати противника;

Enemy prisoner of war team which is responsible for enemy prisoners according to the 5 S's (search, segregate, silence, separate, safeguard) - група для роботи 3 полоненими, що виконуе п'ять задач (обшук, загальна ізоляція полонених, заборона спілкування, ізолячія один від іншого, охорона);

FFIR (friendly forces information requirement) - пошук інформації про дружні війська;

FO (forward observers) - передовий спостерігач, коригувальник вогню;

FOB (forward operating base) - база передового розгортання;

Give me all the PIR (priority information requirement) - обшукати ворога (пошук пріоритетної інформачії, інформація про ворога);

Guard point - сторожовий пункт;

HEDP (high explosive dual purpose) - граната;

HET (Heavy Equipment Transporter) - вантажна платформа;

HUMINT (Human intelligence) - агентурна розвідка;

IED (Improvised Explosive Device) - саморобний вибуховий пристрій;

IMINT (imagery intelligence) - візуальна розвідка;

LRP (Logistical release point) - (батальйонний) пункт видачі матеріальних засобів, пункт бойового постачання;

LTA (local training areas) - тренувальні ділянки;

MCOO (modified combined obstacle overlay) - модифікована комплексна схема перешкод;

MDMP (military decision making process) - процес прийняття військових рішень;

METT-TC (mission, enemy, terrain and weather, troops and support available, time available, civil considerations) - бойове завдання, склад ворога, рельєф місчевості і погоду, час, доступні війська, час, цивільний фактор;

MGRS (military grid reference system) - військова система прямокутних координат США;

XLinguae, Volume 14 Issue 2, April 2021, ISSN 1337-8384, eISSN 2453-711X 
MRE (meal, ready to eat) - Сухий пайок. MRE is individual food ration, used in field environment by the US Army. Notably, in 1990s this abbreviation was decrypted as meals rejected by everyone. Since then, MREs underwent many changes and updates, many drawbacks were eliminated and with new items on the menu the decryption of the acronym MRE returned to its normal self. Ukrainian MRE's are currently undergoing the transition process in order to be more diverse and correspond to the international standards.

MSR (Main Supply Route) - мapupym;

NCO (non-commissioned officer) - сержантський та старшинський склад, старший сержант, відповідальний сержант (офічер, який дослужився до звання з самого початку служби);

NEO (noncombatant evacuation operations) - операціï з евакуачії иүивільного населення;

NTV (non tactical vehicle) - машина небойового призначення;

NVGs (night vision goggles) - окуляри нічного бачення;

OIC (Officer in charge) - відповідальний, головний офіцер на ділянці;

OOTW (operations other than war) - операиії невоєнного типу;

OPFOR (opposing force) - умовний противник, війська противника;

OPSEC(operations security) - безпека операцій;

ORP (Objective Rally Point) - пункт збору поблизу об'єкта дій;

PAO (public affairs officer) - oфiuер зі зв'язків з громадськістю;

PATT Co (partner assisted training team) - партнерський тренувальний батальйон;

PBIEDs (person borne improvised explosive device) - прихований на тілі людини саморобний вибуховий пристрій;

PCC/PCI (pre combat checks and pre combat inspections) - перевірка зброї та обладнання, перевірка готовності груп;

PL (Platoon leader) - командир взводу, but not "plt commander" - difference with Ukrainian;

PMC (Private Military Company) - приватна компанія воєнізованої охорони;

POI (program of instruction) - навчальна програма;

PSC (Private Security Contractor) - приватна компанія-підрядник, щуо надає послуги у сфері безпеки;

PLT SGT (platoon sergeant) - заступник командира взводу, старший сержант;

QRF (Quick Reaction Force) - сили швидкого реагування;

RNS team(reconnaissance team) - розвідувальна група;

ROE (Rules of Engagement) - правила застосування сили (document title);

RSO (Range Safety Officer) - відповідальний за безпеку на діляниі;

RTO (radiotelephone operator) - padioonepamop;

SAW (squad automatic weapon) - кулемет;

SDZ (surface danger zone) - небезпечна зона ураження (на діляниі);

SIGINT (signal intelligence) - радіотехнічна розвідка;

SITMAP (situation map) - карта оперативної обстановки;

SITREP (situation report) - оиінка оперативної обстановки;

SLLS (stop look listen smell) - зупинись, подивись, послухай, понюхай;

SOP (standing operating procedures) - постійна інструкиія про порядок дій, постійно діюча інструкиія;

SPOTREP (SPOT report) - доповідь з місия подіï;

SSORD (Service support order) - наказ по тиловому забезпеченню;

TCCC (tactical combat casualty care) - тактична допомога пораненим в бою;

TF (task force) - оперативно-тактична група;

TOR (terms of reference) - положення про обов'язки і повноваження;

Threat COA (course of action) development - розробка загрозливих варіантів плану дій противника; 
Troop Leading Procedures - процедури управління підрозділами; Ukrainian militarymen often refer to this American abbreviation as "управління військами";

UGS (unattended ground sensor) - автоматичні наземні розвідувально-сигнальні сенсори;

UMCP (unit maintenance collection point) - пункт збору військової техніки, військового обладнання;

VBIED (Vehicle-borne improvised explosive device) - транспортний засіб із саморобним вибуховим пристроєм;

We will SP - повна готовність до виконання місії;

XO (Executive officer) - заступник командира роти, начальник итабу;

CO (Commissioned officer) - офіцер; особа, якій присвоєно офіцерське звання по закінченню ВНЗ.

\section{A.3. Examples of transcoding}

GOTWA Contingency plan: (G) Where I'm going, (O) Others I'm taking, (T) Time of my return, (W) What to do if I don't return, (A) Actions to take if I'm hit/if you're hit - ГОТВА (план дій на випадок непередбаченої ситуації: Куди відправляється командир, хто йде з командиром, час відправлення/повернення, що робити, якщи командир не повернувся, дії у випадку контакту з ворогом);

GP-25 (under barred grenade launcher) - ГП-25 (гранатомет підствольний);

IFOR (Implementation Force) - ІФОР (Сили Виконання Угоди у Боснії $i$ Гериеговині);

KFOR (Kosovo Force) - КФОР (Міжнародні сили з підтримки миру в Косово); MEDEVAC (Medical Evacuation) - МЕДЕВАК (медична евакуаиія);

OPORD (Operational order) - ОПОРД (бойовий наказ/оперативний наказ);

OCOKA(OAKOC) within the METT-TC, about the terrain: observation/fields of view, cover and concealment, obstacle (existing: lakes, rivers, trees and reinforced: tank ditches), mines, key terrains, avenues of approach, - спостереження, укриття/маскування, перешкоди, ключова місиевість, иляхи підходу;

PKT (Kalashnikov's machine gun tank version) - ПКТ (кулемет Калашникова танковий ККТ);

RGD-5 (hand grenade remote) - РГД-5 (ручна граната дистаниійної діi);

RPG (rocket propelled grenade) - РПГ (реактивна протитанкова граната) ручний протитанковий гранатомет);

RPK (hand machine gun) - РПК (from Russian: “Ручной Пулемет Калашникова”). The common usage of the abbreviation RPK in both Ukrainian and English is an influence from Russian, however, the proper abbreviation in Ukrainian is $P K K-$ ручний кулемет Калашникова;

SALUTE report (Size, Activity, Location, Uniform, Time, Equipment) - звіт Салют (розширені відомості про противника: кількість, діяльність, розташування, уніформа, час (коли виявлено), обладнання та обмундирування;

SPG-9 (tripod-mounted anti-tank recoilless gun) - СПГ (станковий протитанковий гранатомет/безвідкатна гармата);

WARNO (Warning order) - ВОРНО (попередній бойовий наказ, попередній наказ, попереднє розпорядження). 